\title{
THE POLITICS OF DISCOURSE IN THOMAS MORE'S UTOPIA
}

\author{
José María Rodríguez García \\ Universidad de Santiago de Compostela
}

\begin{abstract}
RESUMEN. Además de ser la piedra angular de la literatura utópica moderna, la Utopía de Thomas More proporciona un ejemplo paradigmático de texto doctrinal y de serio ludere en el cual los aspectos de modalización narrativa (e.g., quién habla y con qué o para qué interlocutor; desde qué nivel diegético lo hace) resultan tan importantes como el contenido mismo de las doctrinas expuestas. Al igual que en otras obras señeras del Renacimiento (como el Quijote de Miguel de Cervantes o The Tenth Muse de Anne Bradstreet), el texto principal aparece además encerrado en una compleja red de epístolas, poemas, dedicatorias y palinodias. El propósito principal de estos paratextos es el de dar una dimensión satírica a la descripción del reino de Utopía. Asimismo, la ocultación de la historia de Utopía refuerza la hipótesis de que en esta obra la narración de Raphael Hythlodaeus funciona como elemento legitimador (por contraste irónico) del frágil régimen de los Tudor.
\end{abstract}

ABSTRACT. Besides being the cornerstone of modern utopian fiction, Thomas More's Utopia provides a paradigmatic example of a doctrinal text and a serio ludere in which questions related to the use of narrators (e.g., who speaks and for whom; on which diegetic level each speaker exists) are as important as the content of the doctrines being expounded. As happens in other towering works of the Renaissance (such as Miguel de Cervantes's Don Quixote or Anne Bradstreet's The Tenth Muse), the main text appears buried underneath a thick layer of epistles, poems, dedications, and recantations. The principal function of these paratexts is to give a satirical dimension to the description of the kingdom of Utopia. Just as important, the silencing of Utopia's history reinforces the hypothesis that in More's fiction, Raphael Hythlodaeus's narrative works toward legitimating the fragile Tudor regime, with which it is ironically contrasted.

In a well-known Foucauldian essay, Paul Bové characterizes "discourse" as a mode of symbolic production that enables the constitution of subjects, institutions, and disciplines, all of which in turn become functions of that discourse as the latter reproduces and perpetuates itself in day-to-day practices. ${ }^{1}$ To this first reciprocal relation between the discursive chain and its constitutive functions Bové adds a second one that takes place "between the objects and statements within any discourse. Neither

1. "Discourse," Critical Terms for Literary Study, ed. Frank Lentricchia and Thomas McLaughlin (Chicago: U of Chicago P, 1990), p. 52. 
can be studied without seeing it in its relation to the other" (p. 57; author's emphasis). Discourses are about something external to themselves, even if there are inevitably many mediations between the entities of which any discourse speaks and the signs with which it speaks. The student of discourse needs to take account of both these unreliable signs and the elusive realities they point to as he analyzes any given set of utterances. Bové neglects to explain that acknowledging the centrality of this second relation entails a significant departure from Michel Foucault's arguments for the entrapment of discursive practices in their own self-referential mechanisms and for the non-referentiality of the linguistic sign generally. ${ }^{2}$ Such a departure is nevertheless very important in political historiography and scientific writing, two domains in which the truth-value of a discourse lies in its ability to, on the one hand, register accurately the changes that take place in phenomenal reality, and, on the other hand, empower a human agent to induce further changes in that reality in a planned manner.

The functions and statements that collectively constitute what Foucault calls "l'ordre du discours" can be ascertained and critiqued, in the case of utopian narratives, by attending to the following questions: first, who speaks in the text, in what person, from which institutional site, and under whose authority; second, what manner of argumentation (e.g., logical, analogical) is being used; and third, what the main purpose of the discourse really is (e.g., to control reality; to encourage, test, or even frustrate the reader's capacity to trust a totalizing picture of reality). ${ }^{3}$ Accordingly, my chosen strategy to approach the political and the narratological aspects of Thomas More's The Best State of a Commonwealth and the New Island of Utopia (1516) consists in exploring the ways in which the changing interactions between subject (the person who speaks), discourse (the mode or manner of speaking), and institutions of learning (the place from where, and the authority under which, the subject speaks) induce a realignment of social relations as well as new compartmentalizations and hierarchies in the production of knowledge. The chief contrast that needs to be accounted for occurs between two types of characters. On the one hand, there are those characters who are granted the right to withdraw from the routine role that society has assigned to them, so that they can assume each his own individual perspective and voice-they become interpreters and narrators. And on the other hand, there are also those who remain immersed in the automatism of everyday chores-they are not granted the privilege of interpretation. As Pierre Bourdieu writes in The Logic of Practice,

2. Foucault writes in The Archaeology of Knowledge (and "The Discourse on Language"), trans. A.M. Sheridan Smith (New York: Pantheon, 1972): "This exchange [between functions] never involve[s] anything but signs. Discourse thus nullifies itself, in reality, in placing itself at the disposal of the signifier" (p. 228).

3. See in this connection chapter 4 of Foucault's The Archaeology of Knowledge, entitled "The Formation of Enunciative Modalities" (pp. 50-55). 
The status of an observer who withdraws from the situation [of practice] to observe implies an epistemological, but also a social break, which most subtly governs scientific activity when it ceases to be seen as such, leading to an implicit theory of practices that is linked to forgetfulness of the social conditions of scientific activity. 4

The Utopia uses the so-called autoptic or "I"-witness stance to filter a series of events and descriptions through the consciousnesses of individual European characters. To the extent that these characters abandon the utopian world just visited to behold it at a distance, and from that vantage point address a specific audience in England, they allow themselves to be (to say it with Bourdieu) "forgetful" of the many frictions and dysfunctions that inevitably assail the everyday practices of a highly disciplined collectivity.

In the Utopia, More-the-character reframes Raphael Hythlodaeus's original firstperson account by including in the version offered to the reader a detailed description of his -More's- locus standi (his precise allegiances to the English ruling elite and to European humanism) as well as of his locus scribendi (the conditions under which he converses with Hythlodaeus and turns the latter's discourse on Utopia into a book). ${ }^{5}$ Specifically, More represents himself as a friend of humanist Peter Giles and as Henry VIII's loyal state official, thus producing an effect of immediacy and actuality from which the account of the seemingly perfect yet tragically flawed Utopia also benefits. More's Janus-faced identity as cosmopolitan sage and English royal servant invests him with the prestigious humanist curiositas necessary to investigate a wide spectrum of disciplines and with the more pressing responsibility to gather whatever new intelligence about distant powers might affect England's interests overseas. It is often pointed out that such a strong identity protects More against any possible charges of subverting the established order of the English monarchy. In a way, his ambassadorial position assures his audience that he represents (incarnates as well as interprets) the interests of the Tudor dynasty, and consequently will never embrace the ideology and constitution of the Utopians.

Less attention has been paid to the complex array of frames and prefatory materials that bury the narrative of events under a thick layer of spurious philological commentary. The reason for this relative neglect is, I believe, that some of these shorter texts were added progressively to the preexisting text (Books I and II plus Peter Giles's and William Budé's pieces) as the latter went through five printings in four different countries in the space of only four years: Louvain (1516), Paris (1517), Basel

4. The Logic of Practice, trans. Richard Nice (Stanford: Stanford UP, 1990), p. 33.

5. Among the most useful brief discussions of the significance of More's self-representations by means of a letter and a dialogue are Alexandre Cioranescu, L'avenir du passé. Utopie et littérature (Paris: Gallimard, 1972), pp. 92-95; Stephen Greenblatt, Renaissance Self-Fashioning: From More to Shakespeare (Chicago: U of Chicago P, 1980), pp. 33-37; and Harry Berger, Jr., Second World and Green World: Studies in Renaissance Fiction-Making (Berkeley: U of California P, 1988), pp. 25-36. 
(March and November, 1518), and Florence (1519). By 1519 the original text had incorporated a cumulative total of eight introductory epistles and poems, to which we must add, as part of this growing external frame, the peroration and conclusion that come at the close of Hythlodaeus's account in Book II. Together, these learned paratexts must have presented themselves to the sixteenth-century reader as a platform of legitimacy worthy of attention and respect in a wide European context at the same time as they directed the reader's attention to the constructedness and fictive status of many of the epistles and prologues. ${ }^{6}$ The eight items, which combine forms of advance praise with various clues on how to interpret the relation between the two Books, are as follows: the letters of "Erasmus of Rotterdam to John Froben," "William Budé to Thomas Lupset," "Peter Giles to Jerome Busleyden," "John Desmarais to Peter Giles," and "Jerome Busleyden to More," and the three poems by scholars living in Flanders and the Netherlands. What these letters and poems make clear is that the political and social institutions of Utopia should not be seen as a foil to existing English institutions. Morethe-character-narrator acknowledges this much when he recalls his initial hesitation to have the book published, claiming that his main purpose in writing his work was to entertain his humanist friends with a philologist's joke not unlike that of Cervantes in Don Quixote, a book in which even the hidalgo's horse, Rocinante, is cast in a paratextual poetic dialogue as the interlocutor of El Cid's own Babieca. The prefatory materials in More's work also include some fictional paratextual elements: a poem by Anemolious (Raphael Hythlodaeus's nephew) together with a map and the alphabet of Utopia.

The Utopia is a sophisticated literary game, and as such it demands sophisticated responses from those who decide to take part in it. Chief among these players are the writers of the prefatory epistles. Interestingly, two primary functions of literary games in the increasingly centralized early modern state are to encourage the socialization of its subjects and to replace forms of disciplinary coercion with forms of verbal aggression. In his own narrative game More consciously adapts, as the main structural axes of the discourses on Utopia, the humanist dialogue (a more civilized and disinterested version of the belligerent medieval debate) and the formal prose satire (which already in Roman literature features an urbane first-person spokesman and an adversarius). ${ }^{7}$ Not only does Utopia begin as a dialogue and end as a satire, but, as

6. For the places in the Low Countries and England where both the prefatory materials and the Utopia were written and the order of their composition, see J.H. Hexter, "The Composition of Utopia," in The Complete Works of St Thomas More, vol. 4: Utopia, ed. Edward Surtz, S.J., and J.H. Hexter (New Haven: Yale UP, 1965), pp. xvi-xxiii. All references to G.C. Richard's standard English translation (pub. 1923) of the Latin original of the Utopia will be to Surtz and Hexter's edition and will be indicated by page number alone after each quotation or paraphrase.

7. See Miguel Martínez López, "Towards a Definition of English Utopian Literature," Investigaciones filológicas anglo-norteamericanas. Actas del "I Congreso de Lengua y Literatura AngloNorteamericana”, ed. Lucía Mora González (Cuenca: Ediciones de la Universidad de Castilla-La Mancha, 1994), p. 462. 
explained by Stephen Greenblatt, in the presentation of Utopian customs and juridicopolitical institutions (Greenblatt's main example is the regulation of travel within the realm) it repeatedly enacts an ironic shift from the naïve suggestion of absolute mobility to the reality of constraint (pp. 40-41). Even before More explicitly affirms on the last page of the Utopia that he "cannot agree with all that [Raphael Hythlodaeus] said" (p. 245), it is clear that More cannot and will not be converted to a program for the reformation of English institutions based on the same communist policies implemented in Utopia. Just before Hythlodaeus delivers his discourse, More tells him: "you must not force upon people new and strange ideas which you realize will carry no weight with persons of opposite conviction" (p. 50). The problem is one of authority and legitimation, as the continuation of this passage makes explicit: "On the contrary, by the indirect approach you must seek and strive to the best of your power to handle matters tactfully" (p. 50). This exhortation notwithstanding, Hythlodaeus gives a straightforward account of the imaginary commonwealth, neglecting to use as much care as More recommends. Appropriately enough, it is More as both empirical author and external narrator who handles his book tactfully, using as part of his indirect approach to the subject of England's and Utopia's respective constitutions his unwillingness to present his narration in the form of a true dialectical argument. Note, for instance, that More defers his intended debate with Hythlodaeus until they have "another chance to think about these matters more deeply and to talk them over with him more fully" (p. 245). The book can therefore be described as a juxtaposition of stories rather than an interlocking of arguments and exchanges. The intercultural dialogue just mentioned is indefinitely postponed. Only authorized individuals such as a Cardinal or a royal councillor can debate on matters as weighty and as delicate as the legitimacy of ownership institutions and of strongly hierarchized political systems. Conversely, only a landless adventurer such as Hythlodaeus would conceivably dare to uphold the communist constitution of Utopia unconditionally.

Timothy J. Reiss has observed that the fact that Hythlodaeus, the Utopians, and even More agree on some fundamental issues is not the result of a mutual negotiation and ensuing compromise. ${ }^{8}$ They simply share a few common predispositions. In other words, none of the three parties involved as either protagonists or interlocutors in the series of conversations that constitute the book (the Utopians, Hythlodaeus, and the humanist circle of which More is a prominent member) really undergoes profound changes because of a productive contact with the other two. If there is any debate or negotiation of cultural positions whatsoever, any possibility of a serious engagement with questions of cultural identity and cultural change, this must necessarily take place in Book I, in the relaxed atmosphere of the garden. Although Hythlodaeus's account of Utopia in Book II has traditionally been looked at as the thrust of More's work, the mention of specific

8. The Discourse of Modernism (Ithaca: Cornell UP, 1982), pp. 129-32. 
historical problems with hints at their specific historical causes happens only in Book I. Only there do we find several financially and intellectually independent characters, each of whom is therefore entitled to become an interpreter and publicizer (if so he wishes) of his own or of another's culture. But these seemingly independent characters are also clearly identified by their condition of official representatives of the Church of Rome (Cardinal Morton) and the King of England (Thomas More). It is as appointed representatives of a higher political power rather than as disinterested humanists that these high personages are granted the privilege of interpretation. More and Morton's narrative location outside Book II, to which they relate almost exclusively as an audience, indicates that they can adopt what Bourdieu calls the totalizing perspective characteristic of those who step outside the world of practice to theorize about it. More can allow himself to listen to Hythlodaeus precisely because the latter lacks the credibility of either himself-More-a royal councillor and ambassador, or Cardinal Morton, or even the renowned humanist Peter Giles, whose name is mentioned several times in connection with the tongue-in-cheek authentication of the texts.

The fact remains, however, that the fictive society described by Hythlodaeus features a number of laws and practices that are judged by More as being more humane than their European counterparts. This has led a majority of commentators to argue that More-the-author splits himself into the subject-positions of More-the-character-narrator and Hythlodaeus, without ultimately merging them into a higher synthesis. Reiss has brilliantly taken this argument one step further, explaining that the tensions between leisure and labor, money and use value, and public liturgy and private meditation (the differences, that is, between England and Utopia) all express an unresolved semiotic dilemma: More appears torn between his nostalgia for a universe of relations with fewer economic and social mediations (a universe characteristic of both Utopia and medieval Europe) and his present reluctance to theorize a program for the restoration of that longed-for and ultimately anachronistic medieval pastoral (pp. 136-37). ${ }^{9}$

As explained by Denise Albanese, a very useful way of identifying the various types of historical consciousness that coexist in the same historical period is by comparing the different ways in which several contemporaneous narratives choose to display -each in its own characteristic manner- changes, transitions, and discontinuities in time and space. ${ }^{10}$ Although by no means contemporaneous, the Utopia (1516) and Francis Bacon's New Atlantis (1623; pub. 1627) are exemplary in this respect. In the Utopia More does not explain the successive stages through which his imaginary kingdom arrived at its present state. Utopia does not have a history proper insofar as this is not articulated anywhere in the book. For his part, Bacon in

9. The tendency of utopian visions to focus almost exclusively on "the stasis of the image" at the expense of "the dynamics of social or historical process" is mentioned in passing in Richard Halpern, The Poetics of Primitive Accumulation: English Renaissance Culture and the Genealogy of Capital (Ithaca: Cornell UP, 1991), p.151.

10. New Science, New World (Durham: Duke UP, 1996), pp. 95-99, 112-15. 
the New Atlantis makes a more decisive attempt to overcome the immobility of Utopian images by recreating what is suppressed in travel accounts such as Hythlodaeus's, namely, the historical patterns of continuity and change by which even a utopian world must have slowly come into being. This process is outlined twice in Bacon's fiction: in the mariner's narration of the Europeans' progressive embracement of Bensalemite ideals, and in the Governor's account of Bensalem's institutional history. ${ }^{11}$ In the Utopia, by contrast, the only transitions between disparate cultures and disparate time frames take place in the external narrative as the reader is transported from the European garden scenes in Book I to the imaginary island in Book II. Furthermore, these transitions involve a progressive watering-down of the original encomium of the Utopians. The Utopia thus moves from the advance praise of the manuscript in the form of familiar epistles by several hands to the two conversations among friends (in Book I), and on to Hythlodaeus's naïve presentation of Utopian institutions (in Book II) and More's final disavowal (the peroration and conclusion). This two-part disavowal amounts to an ironic recantation of the earlier enthusiasm for the disciplinary world of the Utopians. Clearly, for More the superiority of European over non-European cultural formations is shown in Europe's ability to find adequate channels for the circulation and interpretation of unorthodox philosophical texts, such as Hythlodaeus's account of Utopia, without getting into trouble with official institutions.

The presentation of Utopian society as simply a function of the English aristocracy's own discourse of self-legitimation rather than as the end-result of a complex and idiosyncratic historical process indicates that for More discourse can (and perhaps should) operate as a mechanism of containment and control. To paraphrase Bourdieu's incisive comments on the repressive mechanisms of symbolic power, the function of communication that the circulation of discourses fulfills in societies that claim to integrate all their members as autonomous political subjects always conceals a corresponding function of division. ${ }^{12}$ While the primary setting of More's Utopia is the allegedly tolerant and cosmopolitan Europe influenced by Renaissance humanism, in the course of the narrative only certain personages can discuss certain weighty subjects and only within the framework provided by received conventions of writing and speech. Although More's politics of discourse on the surface seems to encourage the free circulation of personal interpretations and meanings (and even of subversive ideas), in practice it downplays the seriousness and the import of whatever utterances might challenge the orthodoxy of official discourse.

11. See José María Rodríguez García, "The Scriptural Intertext of Conversion and Reform: The First and the Last Paragraphs of Francis Bacon's New Atlantis," Proceedings of the XIXth International Conference of AEDEAN, ed. Javier Pérez Guerra et al. (Vigo: Depto. de Filoloxía Inglesa da Univ. de Vigo, 1996), pp. 487-91; “The Sighting of the Pillar of Light in Francis Bacon's New Atlantis," Culture and Power IV: Cultural Confrontations, ed. Chantal Cornut-Gentille D’Arcy (Zaragoza: Librería General, 1999), pp. 241-52.

12. Language and Symbolic Power, trans. Gino Raymond and Matthew Adamson, ed. John B. Thompson (Cambridge: Harvard UP, 1991), pp. 166-67. 